\title{
Pengaruh Atribut Perusahaan dan Faktor Audit Terhadap Keterlambatan Audit pada Perusahaan yang Terdaftar di Bursa Efek Malaysia
}

\author{
Apriayanti ${ }^{1}$, Setyarini Santosa ${ }^{1^{*}}$ \\ ${ }^{1}$ Fakultas Ekonomi, Universitas Internasional Batam \\ Jl. Gajah Mada Baloi Sei Ladi, Batam 29442 \\ *Penulis korespondensi; email: setyarinis@yahoo.com
}

\begin{abstract}
ABSTRAK
Keterlambatan audit adalah jarak waktu antara tanggal neraca dengan tanggal laporan audit ditandatangani. Tujuan penelitian ini adalah untuk menganalisis pengaruh atribut perusahaaan dan faktor audit terhadap keterlambatan audit. Penelitian ini menggunakan sampel 611 perusahaan yang terdaftar di Malaysian Stock Exchange yang diambil pada periode tahun 2006 sampai dengan 2011. Variabel independen yang digunakan adalah ukuran perusahaan, debt equity ratio, profitabilitas, subsidiari dari perusahaan multinasional, ukuran kantor audit, audit fees, tipe industri, klasifikasi industri, umur perusahaan, tahun tutup buku perusahaan dan opini audit. Dengan menggunakan regresi linier berganda untuk analisis data, diperoleh hasil penelitian yang menunjukkan bahwa semua variabel independen memiliki pengaruh yang signifikan terhadap keterlambatan audit, kecuali variabel tahun tutup buku perusahaan ternyata tidak memiliki pengaruh yang signifikan terhadap keterlambatan audit.
\end{abstract}

Kata kunci: Keterlambatan audit, atribut perusahaan, faktor audit.

\begin{abstract}
Audit delay is interval of days between balance sheet date and audit report date. The purpose of this research is to analyze the effect of company attributes and audit factors to audit delay. This research uses 611 companies listed in Malaysian Stock Exchange from the period of 2006 until 2011 as sample. The independent variables used are size of the company, debt to equity ratio, profitability, subsidiaries of multinational companies, audit firm size, audit fees, industry type, age of company, company financial year end, and audit opinion. The method of analysis in this research is multiple linear regressions. The results of this study shows that size of the company, debt to equity ratio, profitability, subsidiaries of multinational companies, audit firm size, audit fees, industry type, age of company, and audit opinion have significant influence on audit delay while financial year end does not have significant influence on audit delay.
\end{abstract}

Keywords: Audit delay, company attributes, audit factors.

\section{PENDAHULUAN}

Menurut SFAC no 2, yaitu qualitative characteristic of accounting information, karakteristik primer kualitas informasi akuntansi adalah relevance dan reliable. Relevance adalah kemampuan informasi untuk mempengaruhi keputusan yang akan dan/atau telah diambil. Informasi yang relevan membantu investor, kreditor dan pemakai laporan keuangan lain untuk melakukan evaluasi atas kejadian masa lalu, saat ini maupun kejadian dimasa yang akan datang (predictive value). Selain itu, informasi tersebut juga diguanakan untuk konfirmasi atau mengkoreksi ekspektasi sebelumnya (feedback value). Oleh karenanya informasi harus tersedia untuk pengambilan keputusan sebelum informasi tersebut kehilangan kapasitasnya untuk mempengaruhi pengambilan keputusan 
(timeliness). Singkatnya, agar relevan, maka informasi harus memiliki nilai predictive, feedback value dan sekaligus informasi tersebut harus disajikan secara tepat waktu atau timeliness (Belkaoui 2004; Kadir 2011).

Jika laporan keuangan perusahaan dipublikasikan maka aka nada ketentuan ketepatan waktu untuk menyampaikan laporan keuangan yang diatur oleh instansi yang berwenang di masing-masing pasar modal. Di Malaysia, hal ini diatur dalam persyaratan pendaftaran perusahaan di Bursa Efek Malaysia Berhad dalam Bab II (2.03-2) dan Bab IX (9.23-2). Peraturan tersebut mengharuskan perusahaan menyampaikan laporan keuangan secara tepat waktu dan mempublikasikan laporan keuangan selambat-lambatnya pada akhir bulan keenam setelah tanggal laporan keuangan tahunan perusahaan. Dalam konteks Indonesia, berdasarkan peraturan BAPEPAM nomor Kep-36/Kep/PM/2003 tentang Kewajiban Penyampaian Laporan Keuangan Berkala, dinyatakan bahwa laporan keuangan tahunan dan laporan akuntan harus disampaikan kepada Bapepam paling lambat pada akhir bulan ketiga setelah tanggal laporan keuangan (Shulthoni 2012).

Perbedaan waktu terjadi antar tanggal laporan keuangan dan penyelesaian penyusunan laporan keuangan serta tanggal publikasi laporan keuangan karena laporan keuangan yang telah selesai disusun oleh perusahaan harus diaudit dulu oleh akuntan publik sebelum dipublikasikan. Proses audit itu sendiri juga membutuhkan waktu. Hal ini dapat mengakibatkan keterlambatan publikasi laporan keuangan. Keterlambatan audit atas laporan keuangan tersebut biasanya karena adanya masalah dalam laporan keuangan perusahaan sehingga auditor memerlukan waktu yang lebih lama dalam penyelesaian audit. Dengan demikian, ketepatan waktu pelaporan keuangan selain tergantung pada perusahaan selaku penyusun laporan keuangan juga tergantung pada akuntan publik yang mengaudit laporan keuangan perusahaan tersebut.

Keterlambatan publikasi laporan keuangan akan berdampak pada meningkatnya ketidakpastian atas keputusan yang diambil dari informasi yang ada didalam laporan keuangan. Untuk menghindari dampak dari keterlambatan publikasi laporan keuangan, maka laporan keuangan harus dipublikasikan secara tepat waktu. Penelitian yang dilakukan untuk mengetahui faktor-faktor yang menyebabkan terjadinya keterlambatan audit telah dilakukan sebelumnya di beberapa negara, misalnya di US oleh Ashton, Willingham, dan Elliot (1987), di Canada oleh Ashton, Graul, dan Newton (1989), di New Zealand oleh Carslaw dan Kaplan (1991), di Zimbabwe oleh Owusu-Ansah (2000), di Bangladesh oleh Karim dan Ahmed (2005), di Indonesia oleh Rachmawati (2008), di Malaysia oleh Ishak, Sidek \& Rashid (2010); Nor-Shafie dan Hussein (2010) dan di Nigeria oleh Oladipupo (2011). Karena objek penelitian, tahun penelitian, dan variabel yang digunakan berbeda-beda, maka hasil penelitian yang pernah dilakukan sebelumnya beragam. Penelitian ini diharapkan dapat memberikan kontribusi mengenai faktor apa saja yang secara signifikan berpengaruh pada keterlambatan audit dengan menggunakan variable yang berupa atribut yang diturunkan dari perusahaan dan dari auditornya. Atribut perusahaan dan faktor audit secara bersama-sama akan dianalisis karena keterlambatan audit amat tergantung pada kinerja perusahaan dan auditornya.

Keterlambatan audit adalah rentang waktu antara tanggal tutup tahun buku perusahaan atau tanggal neraca hingga tanggal diterbitkannya laporan audit oleh Kantor Akuntan Publik yang mengaudit perusahaan tersebut (Ashton et al. 1989, Yaacob dan Ahmad 2011, Al-Ghanem dan Hegazy 2011). Agar informasi akuntansi yang dihasilkan menjadi relevan seperti yang dikehendaki dalam SFAC No 2, maka informasi tersebut harus mengandung aspek predictive value dan feedback value dan oleh karenanya informasi yang dihasilkan harus dapat tersaji secara tepat waktu atau timeliness (Belkaoui 2004, Kadir 2011). Apabila batas waktu penyampaian laporan keuangan tersebut terlambat, maka, informasi akuntansi yang terkandung dalam laporan keuangan tersebut dapat dikatakan kehilangan kemampuannya untuk membantu pengambilan keputusan.

Penelitian mengenai keterlambatan audit telah dilakukan di beberapa negara seperti di Hongkong, New Zealand, Kanada, Zimbabwe, Perancis, China, Kuwait, Nigeria, Malaysia termasuk juga di Indonesia. Tiap negara memiliki peraturan tersendiri mengenai batas waktu keterlambatan publikasi laporan keuangan. Di Malaysia, hal ini diatur dalam persyaratan pendaftaran perusahaan di Bursa Efek Malaysia Berhad dalam Bab II (2.03-2) dan Bab IX (9.23-2). Peraturan tersebut mengharuskan perusahaan menyampaikan laporan keuangan secara tepat waktu dan mempublikasikan laporan keuangan selambat-lambatnya pada akhir bulan keenam setelah tanggal laporan keuangan tahunan perusahaan.

Hashim dan Rahman (2011) juga telah melakukan penelitian pada 288 perusahaan yang terdaftar di Bursa Efek Malaysia dari tahun 2007 sampai dengan tahun 2009. Hasil penelitian 
tersebut membuktikan bahwa keterlambatan penyajian laporan audit perusahaan di Malaysia terjadi sekitar 36 hari sampai dengan 184 hari. Faktor yang secara signifikan berpengaruh terhadap keterlambatan tersebut adalah audit committee independence, audit committee expertise, dan ukuran perusahaan. Sedangkan audit committee meeting, ukuran kantor audit dan profitabilitas tidak berpengaruh secara signifikan terhadap keterlambatan audit.

Aubert (2009) melakukan penelitian tentang keterlambatan pelaporan laporan keuangan perusahaan di negara Perancis dengan menggunakan data perusahaan dari tahun 1997 sampai dengan tahun 2002. Penelitian tersebut membuktikan bahwa perusahaan mempublikasikan laporan keuangan mereka rata-rata 116.07 hari setelah tahun fiskal.

Penelitian serupa juga dilakukan oleh Fagbemi dan Uadiale (2011) mengenai ketepatan waktu penyelesaian laporan audit pada perusahaan yang terdaftar di Nigerian Stock Exchange. Penelitian tersebut menunjukkan bahwa rata-rata hari yang diperlukan dalam penyelesaian pelaporan keuangan perusahaan sebanyak 141 hari dan rata-rata penyiapan laporan audit selama 31 hari.

McGee dan Yuan (2012) melakukan penelitian tentang keterlambatan audit pada perusahaan di China. Penelitian tersebut membandingkan hasil penelitian dengan dua negara lainnya yaitu Amerika dan Eropa. Hasilnya menunjukkan bahwa perusahaan di China biasanya mempunyai keterlambatan audit yang lebih lama dan yang paling cepat adalah di Amerika.

Penelitian dengan sampel 465 perusahaan di pasar modal Kanada dilakukan oleh Ashton, Graul, dan Newton (1989) perusahaan sepanjang tahun 1977 sampai dengan tahun 1982. Variabel independen yang digunakan dalam penelitian tersebut adalah ukuran perusahaan, klasifikasi industri, tahun tutup buku perusahaan, ukuran kantor audit, profitabilitas, extraordinary item, kontigensi, dan jenis opini audit. Hasil penelitian tersebut menunjukkan bahwa ukuran perusahaan, tahun tutup buku perusahaan, ukuran kantor audit, dan jenis opini audit mempunyai pengaruh signifikan negatif terhadap keterlambatan audit. Sedangkan klasifikasi industri, profitabilitas, extraordinary item, dan kontigensi mempunyai pengaruh signifikan positif terhadap keterlambatan audit.

Carslaw dan Kaplan (1991) melakukan penelitian pada perusahaan publik di New Zealand pada tahun 1987 dan tahun 1988. Variabel yang digunakan dalam penelitian tersebut adalah ukuran perusahaan, klasifikasi industri, profitabilitas, extraordinary item, opini audit, ukuran kantor audit, tahun tutup buku perusahaan, jenis kepemilikan perusahaan, dan proporsi hutang. Hasil dari penelitian tersebut menunjukkan bahwa ukuran perusahaan, klasifikasi industri, dan jenis kepemilikan perusahaan mempunyai pengaruh signifikan negatif terhadap keterlambatan audit. Variabel profitabilitas, extraordinary item, dan opini audit mempunyai pengaruh signifikan positif terhadap keterlambatan audit. Sedangkan ukuran kantor audit dan tahun tutup buku perusahaan tidak menunjukkan adanya pengaruh yang signifikan terhadap keterlambatan audit.

Ng dan Tai (1994) melakukan penelitian pada perusahaan di Hong Kong pada tahun 1990 dan tahun 1991. Dalam penelitian tersebut digunakan variabel ukuran perusahaan, persentase perubahan EPS, tahun tutup buku perusahaan, klasifikasi industri, extraordinary item, ukuran kantor audit, opini audit, tingkat diversifikasi, perubahan auditor, dan principal subsidiaries/joint ventures berlokasi di China. Hasil dari penelitian tersebut menyatakan bahwa tahun tutup buku perusahaan, extraordinary item, dan tingkat diversifikasi mempunyai pengaruh signifikan positif terhadap keterlambatan audit. Sedangkan ukuran perusahaan, persentase perubahan EPS, klasifikasi industri, ukuran kantor audit, opini audit, perubahan auditor, dan principal subsidiaries/joint ventures berlokasi di China tidak berpengaruh signifikan terhadap keterlambatan audit.

Owusu-Ansah (2000) melakukan penelitian dengan menguji pengaruh ukuran perusahaan, profitabilitas, gearing ratio, extra-ordinary and/or contingent items, tahun tutup buku perusahaan, kompleksitas operasi dan umur perusahaan terhadap keterlambatan audit. Hasil dari penelitian tersebut membuktikan bahwa ukuran perusahaan, profitabilitas, dan umur perusahaan mempunyai pengaruh signifikan negatif terhadap keterlambatan audit. Sedangkan gearing ratio, extra-ordinary and/or contingent items, tahun tutup buku perusahaan, kompleksitas operasi tidak berpengaruh signifikan terhadap keterlambatan audit.

Kartika (2009) melakukan penelitian pada perusahan di Indonesia. Varibel yang digunakan adalah ukuran perusahaan, laba atau rugi operasi, opini audit, tingkat profitabilitas, dan reputasi auditor sebagai variabel independen dan keterlambatan audit sebagai variabel dependen. Hasilnya membuktikan bahwa ukuran perusahaan dan laba atau rugi operasi mempunyai pengaruh signifikan negatif terhadap keterlambatan audit. Opini audit mempunyai pengaruh signifikan positif terhadap keterlambatan audit. Sedangkan tingkat profitabilitas, dan reputasi auditor tidak berpengaruh signifikan terhadap keterlambatan audit. 
Turel (2010) juga melakukan penelitian serupa mengenai keterlambatan audit pada 319 perusahaan yang terdaftar di Istanbul Stock Exchange pada 31 Desember 2007. Penelitian tersebut menguji lima variabel independen yaitu ukuran perusahaan, ukuran kantor audit, profitabilitas, opini audit, dan klasifikasi industri terhadap satu variabel dependen yaitu keterlambatan audit. Hasilnya membuktikan bahwa opini audit dan profitabilitas mempunyai pengaruh signifikan negatif terhadap keterlambatan audit. Ukuran kantor audit dan klasifikasi industri mempunyai pengaruh signifikan positif terhadap keterlambatan audit. Sedangkan ukuran perusahaan tidak berpengaruh signifikan terhadap keterlambatan audit.

Al-Ghanem dan Hegazy (2011) melakukan penelitian pada 149 perusahaan pada tahun 2006 dan 177 perusahaan pada tahun 2007 di Kuwait Stock Market. Dalam penelitian tersebut menguji enam variabel independen yaitu ukuran perusahaan, persentase perubahan earning per share, klasifikasi industri, ukuran kantor audit, rasio likuiditas, dan rasio debt to asset terhadap variabel dependen yaitu keterlambatan audit. Hasilnya membuktikan bahwa ukuran perusahaan, ukuran kantor audit, rasio likuiditas, dan rasio debt to asset mempunyai pengaruh signifikan negatif terhadap keterlambatan audit. Sedangkan persentase perubahan earning per share dan klasifikasi industri tidak berpengaruh signifikan terhadap keterlambatan audit.

Iyoha (2012) juga melakukan penelitian di Nigeria dengan menggunakan sampel laporan keuangan tahunan perusahaan dari 61 perusahaan yang terdaftar di Nigerian Stock Exchange. Dalam penelitian tersebut variabel yang digunakan yaitu ukuran perusahaan, profitabilitas, umur perusahaan, ukuran kantor audit, dan tahun tutup buku perusahaan. Hasilnya membuktikan bahwa ukuran perusahaan dan tahun tutup buku perusahaan mempunyai pengaruh signifikan negatif terhadap keterlambatan audit. Umur perusahaan mempunyai pengaruh signifikan positif terhadap keterlambatan audit. Sedangkan profitabilitas dan ukuran kantor audit tidak berpengaruh signifikan terhadap keterlambatan audit.

Modugu, Eragbhe, dan Ikhatua (2012) melakukan penelitian pada 20 perusahaan yang terdaftar di Nigeria Stock Exchange dari tahun 2009 sampai dengan tahun 2011. Dalam penelitian tersebut variabel yang digunakan yaitu ukuran perusahaan, rasio debt to equity, profitabilitas, subsidiari dari perusahaan multinasional, ukuran kantor audit, audit fees, dan klasifikasi industri. Hasilnya membuktikan bahwa ukuran perusaha- an dan audit fees mempunyai pengaruh signifikan negatif terhadap keterlambatan audit. Subsidiari dari perusahaan multinasional mempunyai pengaruh signifikan positif terhadap keterlambatan audit. Sedangkan rasio debt to equity, profitabilitas, dan ukuran kantor audit tidak berpengaruh signifikan terhadap keterlambatan audit.

Tabel 1 merupakan ringkasan hasil penelitian di berbagai jurnal yang meneliti tentang keterlambatan audit.

H1: Ukuran perusahaan berpengaruh signifikan terhadap keterlambatan audit.

Beberapa penelitian yang menyatakan bahwa variabel ukuran perusahaan berpengaruh signifikan negatif terhadap keterlambatan audit adalah penelitian yang dilakukan oleh Carslaw dan Kaplan (1991), Owusu-Ansah (2000), Modugu, Eragbhe dan Ikhatua (2012), Nor, Shafie dan Hussein (2010), Hashim dan Rahman (2011) Sedangkan penelitian Wang dan Song (2006) dan Sudrajat (2009) membuktikan bahwa semakin besar ukuran perusahaan maka akan semakin banyak jumlah hari yang dibutuhkan untuk menyelesaikan laporan keuangan perusahaan yang diaudit. Utami (2006), Dogan, Coskun, dan Celik (2007), Meiden (2007), Afify (2009), Shukeri dan Nelson (2011), Kadir (2011) dan Oladipupo (2011) juga melakukan penelitian serupa dengan menggunakan variabel ukuran perusahaan dalam penelitian mereka untuk mengukur keterlambatan audit. Hasil penelitian tersebut menunjukkan bahwa ukuran perusahaan tidak mempunyai pengaruh signifikan terhadap keterlambatan audit.

Besar kecilnya ukuran perusahaan dapat dilihat dari besaran asset yang dimiliki oleh perusahaan. Selain itu, ukuran perusahaan juga dapat dilihat dari banyaknya karyawan, jumlah penjualan dan sebagainya. Pada umumnya perusahan yang tumbuh semakin besar akan diiringi dengan penataan organisasi dan sistem pengendalian internal yang semakin baik. Jumlah karyawan yang semakin meningkat diperlukan seiring pertumbuhan perusahaan, untuk menangani transaksi yang semakin banyak dan kompleks. Internal kontrol perusahaan yang semakin kuat dan dapat diandalkan dapat mengurangi kesalahan dalam penyajian laporan keuangan, hal ini akan menyebabkan waktu audit yang diperlukan akan lebih pendek (Ahmad dan Abidin 2008; Ng dan Tai 1994). Apalagi perusahaan besar juga senantiasa rutin melaksanakan audit sehingga proses audit akan jadi lebih cepat (Ng dan Tai 1994). 
Tabel 1. Ringkasan Hasil Penelitian

\begin{tabular}{|c|c|c|c|c|c|c|c|}
\hline & $\begin{array}{l}\text { Hashim \& } \\
\text { Rahman }\end{array}$ & $\begin{array}{l}\text { Ashton, } \\
\text { Graul, dan } \\
\text { Newton }\end{array}$ & $\begin{array}{c}\text { Carslaw \& } \\
\text { Kaplan }\end{array}$ & $\begin{array}{l}\text { Modugu, P. K., } \\
\text { Eragbhe, E., \& } \\
\text { Ikhatua }\end{array}$ & Iyoha & Turel & $\begin{array}{c}\text { Owusu- } \\
\text { Ansah }\end{array}$ \\
\hline & 2011 & 1989 & 1991 & 2012 & 2012 & 2010 & 2000 \\
\hline Audit committee independence & $\mathrm{S}$ & $* * *$ & $* * *$ & $* * *$ & $* * *$ & $* * *$ & $* * *$ \\
\hline Audit committee expertise, & $\mathrm{S}$ & $* * *$ & $* * *$ & $* * *$ & $* * *$ & $* * *$ & $* * *$ \\
\hline Audit committee meeting, & TS & $* * *$ & $* * *$ & $* * *$ & $* * *$ & $* * *$ & $* * *$ \\
\hline Ukuran kantor audit & TS & $\mathrm{S}(-)$ & $\mathrm{S}$ & TS & TS & $\mathrm{S}$ & $* * *$ \\
\hline Jenis opini audit & $* * *$ & $\mathrm{~S}(-)$ & $\mathrm{S}$ & $* * *$ & $* * *$ & $\mathrm{~S}$ & $* * *$ \\
\hline Audit fees & $* * *$ & $* * *$ & $* * *$ & $\mathrm{~S}$ & $* * *$ & $* * *$ & $* * *$ \\
\hline Ukuran perusahaan & $\mathrm{S}(-)$ & $\mathrm{S}(-)$ & $\mathrm{S}$ & $\mathrm{S}(-)$ & $\mathrm{S}$ & TS & $\mathrm{S}(-)$ \\
\hline Profitabilitas & $\mathrm{TS}$ & $\mathrm{S}(+)$ & $\mathrm{S}$ & $\mathrm{TS}$ & TS & $\mathrm{S}$ & $\mathrm{S}$ \\
\hline Debt to equity ratio & $* * *$ & $* * *$ & $* * *$ & TS & $* * *$ & $* * *$ & $* * *$ \\
\hline Klasifikasi industri & $* * *$ & $\mathrm{~S}(+)$ & $\mathrm{S}$ & $\mathrm{TS}$ & $* * *$ & $\mathrm{~S}$ & $* * *$ \\
\hline Tahun tutup buku & $* * *$ & $\mathrm{~S}(-)$ & $\mathrm{S}$ & $* * *$ & $\mathrm{~S}$ & $* * *$ & $\mathrm{TS}$ \\
\hline Extraordinary item & $* * *$ & $\mathrm{~S}(+)$ & $\mathrm{S}$ & $* * *$ & $* * *$ & $* * *$ & TS \\
\hline Kontigensi & $* * *$ & $\mathrm{~S}(+)$ & $\mathrm{S}(+)$ & $* * *$ & $* * *$ & $* * *$ & $* * *$ \\
\hline Jenis kepemilikan perusahaan & $* * *$ & $* * *$ & $\mathrm{~S}(-)$ & $* * *$ & $* * *$ & $* * *$ & $* * *$ \\
\hline $\begin{array}{l}\text { Subsidiari dari perusahaan } \\
\text { multinasional }\end{array}$ & $* * *$ & $* * *$ & $* * *$ & $\mathrm{~S}$ & $* * *$ & $* * *$ & $* * *$ \\
\hline Umur perusahaan & $* * *$ & $* * *$ & $* * *$ & $* * *$ & $\mathrm{~S}$ & $* * *$ & $\mathrm{~S}$ \\
\hline Gearing Ratio & $* * *$ & $* * *$ & $* * *$ & $* * *$ & $* * *$ & $* * *$ & $\mathrm{TS}$ \\
\hline Kompleksitas Operasional & $* * *$ & $* * *$ & $* * *$ & $* * *$ & $* * *$ & $* * *$ & TS \\
\hline S (-) : Signifikan negatif & $\mathrm{S}(+)$ & : Signifikan 1 & positif & & tidak & aifikan & \\
\hline
\end{tabular}

Ukuran suatu perusahaan dapat memberikan pengaruh yang negatif maupun positif terhadap keterlambatan audit. Perusahaan besar mempunyai sumber dan tenaga akuntan yang cukup, sistem informasi akuntansi yang memadai, sistem internal kontrol yang kuat serta cenderung rutin melakukan audit dan analisis laporan keuangan. Hal ini akan menyebabkan publikasi laporan keuangan relatif lebih cepat. Namun demikian karakteristik perusahaan besar yang cenderung memilliki kompleksitas operasional yang lebih tinggi jika dibandingkan dengan perusahaan kecil akan membutuhkan waktu yang relatif lebih lama dalam proses penyusunan dan proses audit sehingga dapat menyebabkan terjadinya keterlambatan audit (Turel 2010).

H2: Rasio debt to equity berpengaruh signifikan terhadap keterlambatan audit.

Rasio debt to equity merupakan gambaran perbandingan antara utang dan ekuitas dalam pendanaan perusahaan dan menunjukkan kemampuan modal perusahaan yang dapat digunakan untuk memenuhi segala kewajiban perusahaan atau ukuran resiko yang dimiliki oleh perusahaan (Meiden, 2007). Penelitian yang dilakukan oleh Aubert (2009) menunjukkan bahwa variabel rasio debt to equity mempunyai pengaruh signifikan positif terhadap keterlambatan audit. Sedangkan penelitian Utami (2006) dan Shulthoni (2012) menunjukkan bahwa rasio debt to equity tidak mempunyai pengaruh signifikan terhadap keterlambatan audit.

Carslaw dan Kaplan (1991) melakukan penelitian untuk mengukur pengaruh variabel rasio debt to equity terhadap keterlambatan audit perusahaan pada perusahaan di New Zealand pada tahun 1987 dan tahun 1988. Hasil dari penelitiannya membuktikan bahwa variabel rasio debt to equity tidak berpengaruh signifikan pada tahun 1987 terhadap keterlambatan audit dan berpengaruh signifikan pada tahun 1988 terhadap keterlambatan audit. Perusahaan yang memiliki banyak utang pada struktur keuangannya memiliki kepentingan untuk menyelesaikan laporan keuangan yang telah diaudit lebih cepat karena kebutuhan untuk memberikan kesan yang baik terhadap kreditor (Meiden 2007).

H3: Profitabilitas perusahaan berpengaruh signifikan terhadap keterlambatan audit

Profitabilitas adalah kemampuan perusahaan memperoleh laba. Beberapa penelitian yang dilakukan menunjukkan bahwa profitabilitas mempunyai pengaruh signifikan diantaranya Owusu-Ansah (2000), Dogan et al. (2007), Ashton et al. (1989), Carslaw dan Kaplan (1991), dan Lee dan Jahng (2008), Turel (2010) dan Utami (2006). Iyoha (2012) juga menggunakan variabel profitabilitas dalam penelitiannya pada perusahaan di Nigeria Stock Exchange. Hasil dari penelitiannya menunjukkan bahwa profitabilitas tidak ber- 
pengaruh signifikan terhadap keterlambatan audit. Hal yang sama juga dibuktikan oleh penelitian Modugu et al. (2012), Kadir (2011) dan Hashim dan Rahman (2011) dalam konteks penelitian negara Malaysia.

Gitman dan Joehnk (2008) menyatakan profitabilitas merupakan hubungan antara pendapatan dan biaya yang dihasilkan dengan memanfaatkan aset perusahaan secara efektif dalam proses produksinya. Perusahaan yang dapat menghasilkan laba atau memiliki profitabilitas lebih tinggi cenderung akan lebih tepat waktu dalam pelaporan keuangannya. Profitabilitas merupakan berita baik (good news) dan manejer akan cenderung lebih cepat melaporkan laba (good news) daripada rugi (bad news). Hal ini dikarenakan publikasi laba tersebut dapat memberikan dampak pada harga saham dan indikator lainnya. Artinya laba perusahaan dapat mempengaruhi keterlambatan audit (Ng dan Tai, 1994).

H4: Subsidiari dari perusahaan multinasional berpengaruh signifikan terhadap keterlambatan audit

Variabel subsidiari dari perusahaan multinasional relatif jarang digunakan dalam penelitian tentang keterlambatan audit. Variabel ini digunakan dengan anggapan bahwa perusahaan yang memiliki hubungan multinasional akan lebih cepat dalam menyelesaikan laporan keuangan mereka daripada perusahaan lokal. Penelitian yang dilakukan oleh Karim dan Ahmed (2005) menyatakan bahwa variabel subsidiari dari perusahaan multinasional berpengaruh yang signifikan negatif terhadap keterlambatan audit.

Subsidiari dari perusahaan multinasional merupakan perusahaan di negara berkembang yang memiliki hubungan dengan perusahaan multinasional di negara maju. Perusahaan multinasional biasanya akan di audit oleh perusahaan audit berukuran besar seperti Big4 yang dapat menyelesaikan tugas audit dengan lebih cepat dan efisien. Oleh karenanya perusahaan yang merupakan subsidiari dari perusahaan multinasional akan mempersiapkan laporan keuangan mereka lebih cepat setelah berakhirnya periode akuntansi untuk kepentingan konsolidasi (Modugu et al. 2012).

H5: Ukuran kantor audit berpengaruh signifikan terhadap keterlambatan audit

Keterlambatan audit sangat tergantung pada perusahaan dan kantor akuntan publik yang mengaudit perusahaan tersebut. Atribut atau karakteristik kantor audit yang dirasa ber- pengaruh terhadap keterlambatan audit adalah besaran kantor audit. Sudrajat (2009), Iskandar dan Trisnawati (2010), Fagbemi dan Uadiale (2011), Oladipupo (2011), Ashton et al. (1989), Carslaw dan Kaplan (1991), Turel (2010), Rachmawati (2008), dan Shulthoni (2012) meneliti pengaruh variabel ukuran kantor audit terhadap keterlambatan audit. Hasilnya membuktikan bahwa perusahaan-perusahaan yang menggunakan jasa kantor audit internasional (KAP Big4) membutuhkan jumlah hari yang lebih sedikit untuk menyelesaikan laporan keuangan. Artinya ukuran kantor audit mempunyai pengaruh signifikan terhadap keterlambatan audit.

Sedangkan penelitian Ng dan Tai (1994), Karim dan Ahmed (2005), Afify (2009), dan Modugu et al. (2012) menunjukkan bahwa ukuran kantor audit tidak berpengaruh signifikan terhadap keterlambatan audit. Kantor audit yang berukuran besar atau berafiliasi dengan kantor akuntan publik internasional, biasanya memiliki kualitas kerja yang relatif lebih baik dibandingkan kantor audit yang berukuran kecil. Hal tersebut dikarenakan perusahaan audit yang besar memiliki lebih banyak staf atau personil audit, fasilitas-fasiltas audit, teknologi pemeriksaan yang canggih dan lebih berpengalaman dalam bidang audit (Iyoha 2012, Nor et al. 2010). Kualitas pekerjaan ini tampak dari kecepatan kerja kantor akuntan publik dalam melakukan proses audit sehingga mengurangi kemungkinan terjadinya keterlambatan audit. Oleh karenanya hipotesis yang hendak diuji dalam penelitian ini adalah:

H6: Audit fees berpengaruh signifikan terhadap keterlambatan audit.

Selain ukuran kantor audit, audit fees juga diduga mempengaruhi cepat lambatnya penyelesaian audit. Perusahaan yang besar akan memberikan audit fees yang lebih tinggi jika dibandingkan dengan audit fees pada perusahaan kecil. Perusahaan besar memiliki jumlah dan kompleksitas transaksi yang lebih tinggi jika dibandingkan dengan perusahaan kecil. Oleh karenanya, audit pada perusahaan besar membutuhkan jam kerja staff audit yang lebih besar, teknik dan teknologi audit tertentu sehingga menyebabkan tinggi nya audit fee. Hal ini juga akan mempengaruhi ketepatan waktu audit (Modugu et al. 2012). Semakin tinggi audit fees maka waktu yang diperlukan dalam penyelesaian laporan audit lebih pendek.

Untuk itu, audit fees merupakah salah satu variabel yang diduga dapat menyebabkan terjadinya keterlambatan audit. 
H7: Klasifikasi industri berpengaruh signifikan terhadap keterlambatan audit

Klasifikasi industri dapat dibedakan menjadi dua kelompok yaitu perusahaan keuangan dan perusahaan non keuangan (Aktas dan Kargin 2011). Audit pada perusahaan non keuangan membutuhkan waktu relatif lebih lama dibandingkan audit pada perusahaan keuangan terkait dengan adanya audit pos persediaan yang terdapat pada perusahaan non keuangan. Pada klasifikasi perusahaan non keuangan, ada industri tertentu yang memiliki kompleksitas operasional yang cukup tinggi jika dibandingkan kelompok industri lainnya (Afify 2009, Modugu et al. 2012). Kompleksitas tersebut mempengaruhi pengukuran akuntansi, teknik penilaian dan pengungkapan yang digunakan, sehingga memerlukan waktu penyelesaian laporan dan audit yang relatif lebih lama. Proses ini dapat menyebabkan keterlambatan audit pada perusahaan non keuangan. Jenis industri dapat mempengaruhi keterlambatan audit (Carslaw dan Kaplan 1991). Namun demikian, beberapa penelitian lain menyatakan bahwa klasifikasi industri tidak mempunyai pengaruh signifikan terhadap keterlambatan audit, seperti penelitian yang dilakukan oleh Ashton et al. (1987), Ng dan Tai (1994), Ahmad dan Abidin (2008) dan Al-Ajmi (2008).

Penelitian yang dilakukan oleh Carslaw dan Kaplan (1991) serta Iskandar dan Trisnawati (2010) menunjukkan bahwa terdapat pengaruh signifikan negatif antara klasifikasi industri dengan keterlambatan audit. Sedangkan penelitian serupa yang dilakukan oleh Turel (2010) pada perusahaan yang terdaftar di Istanbul Stock Exchange (ISE) pada tahun 2007 menunjukkan adanya pengaruh signifikan positif antara klasifikasi industri dengan keterlambatan audit.

H8: Umur perusahaan berpengaruh signifikan terhadap keterlambatan audit

Umur suatu perusahaan dapat mempengaruhi kualitas praktek akuntansi yang nantinya akan berpengaruh pada lamanya waktu penyajian laporan keuangan. Umur perusahaan merupakan lama waktu suatu perusahaan sejak didirikan sampai tahun penelitian dilakukan (Lianto dan Kusuma 2010, Joshi 2005). Umur perusahaan juga dapat diartikan sebagai jumlah tahun keberadaan perusahaan sejak rapat umum tahunan pertama (Iyoha 2012).

Pada perusahaan yang sudah lama berdiri biasanya mempunyai sistem yang sudah lebih tertata, termasuk prosedur internal kontrol yang sudah semakin teruji sehingga yang dapat mengurangi terjadinya kesalahan dalam penyajian laporan keuangan. Dengan demikian, perusahaan yang telah lama berdiri memiliki kecenderungan untuk tidak mengalami penundaan pelaporan keuangan. Perusahaan yang baru berdiri biasanya kurang memiliki pengalaman terhadap pengendalian akuntansi sehingga menyebabkan penundaan pelaporan keuangan. Artinya semakin lama perusahaan berdiri, maka perusahaan akan memiliki penataan organsisasi dan internal kontrol yang kuat sehingga semakin besar kemungkinan perusahaan akan menyajikan laporan secara tepat waktu (Hope dan Langli 2008).

Owusu-Ansah (2000) menggunakan variabel umur perusahaan sebagai salah satu variabel independen dalam meneliti keterlambatan audit. Data yang digunakan berupa perusahaan yang bergerak di bidang non finansial yang terdaftar di Zimbabwe Stock Exchange. Hasil penelitian menunjukkan bahwa umur suatu perusahaan mempunyai pengaruh signifikan negatif terhadap keterlambatan audit.

Penelitian yang sama juga dilakukan oleh Lianto dan Kusuma (2010) dengan menguji pengaruh variabel umur perusahaan terhadap keterlambatan audit dari tahun 2004 sampai dengan tahun 2008. Hasil dari penelitian tersebut menemukan bahwa adanya pengaruh signifikan positif antara umur perusahaan dengan keterlambatan audit. Sedangkan hasil penelitian Joshi (2005) dan Kadir (2011) menunjukkan bahwa tidak ada pengaruh signifikan antara umur perusahaan dengan keterlambatan audit.

H9: Tahun tutup buku perusahaan berpengaruh signifikan terhadap keterlambatan audit

Tahun tutup buku perusahaan adalah waktu dimana perusahaan menyajikan laporan keuangan pada akhir tahun fiskal (Ahmad dan Abidin 2008). Kebanyakan perusahaan sering terlambat dalam pelaporan dan penyajian laporan keuangan perusahaan, karena banyak perusahaan yang tahun fiskalnya terjadi pada bulan sibuk yaitu bulan Oktober sampai dengan bulan Desember (Iyoha 2012, Ng dan Tai 1994). Audit yang dilakukan selama bulan sibuk diperkirakan akan menyebabkan keterlambatan pelaporan laporan keuangan perusahaan karena penumpukan pekerjaan audit di kantor akuntan publiknya. Penumpukan pekerjaan audit ini mungkin dapat memberikan dampak pada keterlambatan audit. Kantor akuntan publik mungkin perlu melakukan pengrekrutan staf audit yang baru dan membayar upah lembur agar keterlambatan audit bisa diatasi. Jadi tahun tutup buku perusahaan yang 
berada pada bulan sibuk memiliki pengaruh terhadap keterlambatan audit (Ashton et al. 1989, Iyoha 2012, Ng dan Tai 1994). Namun demikian ada pula hasil penelitian yang menyatakan bahwa tidak ada pengaruh pengaruh signifikan antara tahun tutup buku perusahaan terhadap keterlambatan audit (Carslaw dan Kaplan 1991, Nor et al. 2010, Ishak et al. 2010).

H10: Opini audit berpengaruh signifikan terhadap keterlambatan audit

Opini audit merupakan pendapat yang diberikan oleh seorang auditor sebagai pihak yang independen atas kewajaran laporan keuangan yang diaudit. Opini audit merupakan salah satu faktor yang dapat mempengaruhi keterlambatan audit. Perusahaan yang menerima opini wajar tanpa pengecualian dari kantor audit akan lebih cenderung pendek tingkat keterlambatan auditnya. Opini wajar tanpa pengecualian diartikan sebagai berita baik bagi perusahaan. Audit yang dilakukan akan lebih cepat karena tidak diperlukan komunikasi dan diskusi lanjutan antara auditor dengan perusahaan. Jika perusahaan menerima opini audit selain opini wajar tanpa pengecualian, maka proses audit akan cenderung lebih panjang. Dengan demikian kemungkinan untuk terjadinya keterlambatan audit cukup tinggi (Meiden 2007). Opini audit selain opini wajar tanpa pengecualian akan dianggap sebagai berita buruk sehingga perusahaan akan lebih cenderung lambat mempublikasikan laporan keuangannya, dengan alasan sama seperti pengaruh status perusahaan yang mendapatkan laba atau rugi (good news atau bad news) terhadap keterlambatan publikasi laporan keuangan. Selain Meiden (2007), penelitian Lee dan Jahng (2008), Carslaw dan Kaplan (1991), Wang dan Song (2006), Ahmad dan Abidin (2008), Utami (2006) serta Turel (2010) menyatakan terdapat pengaruh signifikan atas opini audit terhadap keterlambatan audit. Sedangkan penelitian Ng dan Tai (1994) dan Shulthoni (2012) yang menggunakan opini audit sebagai salah satu faktor yang mempengaruhi keterlambatan audit membuktikan bahwa opini audit tidak berpengaruh signifikan terhadap keterlambatan audit.

\section{METODE PENELITIAN}

Penelitian ini menggunakan sampel perusahaan terdaftar di Bursa Efek Malaysia dari tahun 2006 sampai dengan tahun 2011. Metode pemilihan sampel yang digunakan adalah purposive sampling. Data yang digunakan adalah data sekunder dari perusahaan yang berupa laporan perubahan posisi keuangan perusahaan, laporan laba rugi perusahaan, laporan auditor independen, catatan atas laporan keuangan dari tahun 2006 sampai dengan tahun 2011, dengan kriteria adanya ketersediaan data yang diperlukan dalam penelitan ini. Sedangkan data tahun pendirian perusahaan berasal dari website masingmasing perusahaan. Jumlah perusahaan yang dijadikan sampel 611 perusahaan dengan observasi selama 6 tahun pada masing-masing perusahaan, sehingga total pengamatan dalam penelitian ini berjumlah 3.666. Dari total pengamatan tersebut, 257 pengamatan merupakan data outlier sehingga yang memenuhi syarat hanya 3409 pengamatan.

Untuk analisis data digunakan regresi linear berganda (Ghozali, 2001). Sedangkan pengolahan data dilakukan dengan bantuan aplikasi komputer SPSS atau Statistical Package for The Social Sciences (Santoso, 2000). Adapun definisi operasional variabel adalah sebagai berikut:

Keterlambatan audit (Modugu et al. 2012, Ahmad dan Abidin 2008)

AUDLAY = Rentang waktu antara tanggal neraca sampai tanggal ditandatanganinya laporan audit.

Ukuran perusahaan (Modugu et al. 2012, Turel 2010)

LASSTS = Log dari total asset perusahaan.

Rasio debt to equity (Modugu et al. 2012, Meiden 2007)

$$
\text { DRAT }=\frac{\text { Total Utang }}{\text { Total Ekuitas }}
$$

Profitabilitas (Iyoha 2012), menggunakan variabel dummy

PRFT $=1$, jika perusahaan melaporkan laba dari operasional perusahaan (operating profit).

$\mathrm{PRFT}=0$, jika perusahaan melaporkan rugi dari operasional perusahaan (operating loss).

Subsidiari dari perusahaan multinasional (Karim dan Ahmed 2005), menggunakan variabel dummy.

$\mathrm{MCM}=1$, jika perusahaan merupakan subsidiari dari perusahaan multinasional.

$\mathrm{MCM}=0$, jika perusahaan merupakan perusahaan lokal.

Ukuran Kantor Audit (Carslaw dan Kaplan 1991, Modugu et al. 2012), menggunakan variabel dummy.

INLNK $=1$, jika kantor audit merupakan kantor audit internasional atau Big 4.

INLNK $=0$,jika kantor audit bukan merupakan kantor audit internasional atau non Big 4. 
Audit Fees (Modugu et al. 2012)

AUDFEE $=$ Audit fees

Klasifikasi Industri (Carslaw dan Kaplan 1991, Al-Ghanem dan Hegazy 2011), menggunakan variabel dummy sebagai berikut:

INDT $=1$, jika perusahaan merupakan perusahaan non keuangan.

INDT $=0$, jika perusahaan merupakan perusahaan keuangan.

Umur Perusahaan (Joshi 2005)

$\mathrm{AGE}=$ Jumlah tahun keberadaan perusahaan sejak pendirian perusahaan sampai tahun penelitian.

Tahun Tutup Buku Perusahaan (Iyoha 2012), menggunakan variabel dummy sebagai berikut:

FINYR $=1$, jika tahun tutup buku terjadi pada bulan Oktober sampai dengan bulan Desember.

FINYR $=0$, jika tahun tutup buku tidak terjadi pada bulan Oktober sampai dengan bulan Desember.

Opini Audit (Turel 2010), menggunakan variabel dummy dengan cara sebagai berikut:

OPINI $=1$, jika perusahaan menerima standar opini (unqualified opini) dari auditor.

OPINI $=0$, jika perusahaan bukan menerima standar opini (unqualified opini) dari auditor.

Sedangkan model regresi yang digunakan adalah:

$$
\begin{aligned}
\text { AUDLAY }= & a+b_{1} \text { LASSTS }+b_{2} \text { DRAT }+b_{3} \text { PRFT + } \\
& b_{4} \text { MCM }+b_{5} \text { INLNK }+b_{6} \text { AUDFEE + } \\
& b_{7} \text { INDT }+b_{8} \text { AGE }+b_{9} \text { FINYR }+b_{10} \\
& \text { OPINI }+\mathrm{e}
\end{aligned}
$$

\section{HASIL PENELITIAN DAN PEMBAHASAN}

\section{Statistik Deskriptif}

Hasil pengolahan data atas statistik deskriptif data disajikan pada Tabel 2 dan Tabel 3.

Dari Tabel 2 tampak bahwa nilai rata-rata keterlambatan audit sebesar 102,82 hari. Hal ini berarti keterlambatan audit yang terjadi di Malaysia berkisar 102 sampai 103 hari, dengan standar deviasi sebesar 18,5 hari. Rata-rata keterlambatan audit ini merupakan rata-rata keterlambatan audit untuk seluruh perusahaan sampel, dari perusahaan yang ukuran (total aset) nya terkecil, yaitu Infortech Alliance Berhad yang bergerak dibidang teknologi sampai dengan perusahaan yang memiliki aset terbesar yaitu Public Bank Berhad yang bergerak di bidang jasa perbankan. Hasil tersebut masih berada di bawah batas penyajian laporan keuangan yang telah ditetapkan oleh Bursa Efek Malaysia yaitu batas penyajian yang ditetapkan 180 hari.

Variabel rasio debt to equiy dalam penelitian ini menunjukkan bahwa perusahaan sampel memiliki resiko yang cukup beragam jika dilihat dari kemampuan modal sendiri nya untuk melunasi seluruh hutang yang dimilikinya. Data ini memiliki nilai minimum dan nilai maksimum sebesar 1,79 dan 188,91 . Nilai maksimum menunjukkan bahwa modal perusahaan kurang lebih sebesar 189 kali dari besaran hutang yang ditanggungnya. Data ini dimiliki oleh perusahaan yang bergerak dibidang Infrastructure Project Company (IPC). Perbedaan cukup besar atas rasio kedua perusahaan tersebut menunjukkan keragaman resiko yang cukup tinggi seperti tampak pada standar deviasi dalam tabel tersebut.

Variabel audit fees dalam penelitian ini menunjukkan keragaman data yang cukup besar yaitu dalam range RM 5.000 sampai RM 4.357.000, dengan rata-rata sebesar RM 207.531,64. Meskipun jika dilihat dari total asset menyatakan bahwa ukuran perusahaan sampel yang diaudit tidak beragam. Sedangkan statistik deskriptif variabel umur perusahaan menunjukkan bahwa rata-rata umur perusahaan sampel adalah 30,72 tahun. Perusahaan yang tertua dari perusahaan yang dijadikan sampel penelitian adalah Nestle (M) Berhad yang telah berdiri 145 tahun yang lalu jika dihitung sampai pada saat penelitian ini dilakukan, tahun 2012.

Tabel 3 menunjukkan bahwa 96.3\% perusahaan sampel merupakan perusahaan lokal yang tidak merupakan subsidiari dari perusahaan multinasional dan $97 \%$ bergerak di sektor non keuangan. Sebesar $82.7 \%$ perusahaan sampel melaporkan laba dari aktivitas operasionalnya. Jadi sebagian besar merupakan perusahaan lokal yang bergerak di sektor non keuangan dan cukup profitable. Kantor akuntan publik yang direkrut perusahaan sampel hampir seimbang antara kantor akuntan publik yang berafiliasi dengan kantor akuntan publik internasional dan yang bukan, meskipun masih sedikit lebih besar pada yang menggunakan auditor afiliasi internasional.

Variabel tahun tutup buku perusahaan dalam penelitian ini menunjukkan bahwa tahun tutup buku 61,5\% perusahaan sampel di Malaysia banyak terjadi selama bulan sibuk yaitu di bulan Oktober sampai Desember. Hasil penelitian juga menyatakan bahwa perusahaan go public yang ada di Malaysia hampir 99\% memperoleh standar opini audit atau unqualified opinion. 
Tabel 2. Statistik Deskriptif Variabel-Variabel Penelitian

\begin{tabular}{lrrrrr}
\hline & $\mathrm{N}$ & Minimum & Maksimum & \multicolumn{1}{c}{ Rata-rata } & \multicolumn{1}{c}{ Std. Deviasi } \\
\hline AUDLAY & 3409 & 25 & 151 & 102,81959519 & 18,48224350 \\
LASSTS & 3409 & 6,41446827 & 11,39691557 & 8,50640162 & 0,68700829 \\
DRAT & 3409 & 1,78710055 & 188,91134449 & 116,552007 & 40,6331583 \\
AUDFEE & 3409 & 5.000 & 4.357 .000 & $207.531,64$ & $330.228,675$ \\
AGE & 3409 & 7 & 145 & 30,71839294 & 20,15523806 \\
\hline
\end{tabular}

Keterangan:

AUDLAY $=$ Keterlambatan audit

LASSTS = Ukuran perusahaan

DRAT $=$ Rasio debt to equity

AUDFEE $=$ Audit fees

AGE = Umur perusahaan

Tabel 3. Statistik Deskriptif pada Variabel Dummy

\begin{tabular}{|c|c|c|c|}
\hline Variabel & Kategori & Frekuensi & Persen \\
\hline PRFT & $\begin{array}{l}1 \text { =jika perusahaan melaporkan laba dari operasional perusahaan (operating } \\
\text { profit). } \\
0=\text { jika perusahaan melaporkan rugi dari operasional perusahaan (operating loss). }\end{array}$ & $\begin{array}{r}2.818 \\
591\end{array}$ & $\begin{array}{l}82,7 \\
17,3\end{array}$ \\
\hline MCM & $\begin{array}{l}1=\text { jika perusahaan merupakan subsidiari dari perusahaan multinasional. } \\
0=\text { jika perusahaan merupakan perusahaan lokal. }\end{array}$ & $\begin{array}{r}126 \\
3.283 \\
\end{array}$ & $\begin{array}{r}3,7 \\
96,3\end{array}$ \\
\hline INLNK & $\begin{array}{l}1=\text { jika kantor audit merupakan kantor audit internasional atau Big } 4 . \\
0=\text { jika kantor audit bukan merupakan kantor audit internasional atau Big } 4 .\end{array}$ & $\begin{array}{l}1.948 \\
1.461\end{array}$ & $\begin{array}{l}57,1 \\
42,9\end{array}$ \\
\hline INDT & $\begin{array}{l}\text { 1= jika perusahaan merupakan perusahaan non keuangan. } \\
0=\text { jika perusahaan merupakan perusahaan keuangan. }\end{array}$ & $\begin{array}{r}3.306 \\
103 \\
\end{array}$ & $\begin{array}{r}97,0 \\
3,0 \\
\end{array}$ \\
\hline FINYR & $\begin{array}{l}1=\text { jika tahun tutup buku perusahaan terjadi pada bulan oktober sampai dengan } \\
\text { bulan desember. } \\
0=\text { jika tahun tutup buku perusahaan tidak terjadi pada bulan oktober sampai } \\
\text { desember. }\end{array}$ & 2.098 & 61,5 \\
\hline OPINI & $\begin{array}{l}1=\text { jika perusahaan menerima standar opini (unqualified opini) dari auditor. } \\
0=\text { jika perusahaan bukan menerima standar opini (unqualified opini) dari } \\
\text { auditor. }\end{array}$ & 3.369 & 98,8 \\
\hline
\end{tabular}

Tabel 4. Hasil Uji t

\begin{tabular}{lcrcc}
\hline \multicolumn{1}{c}{ Variabel } & Unstadardized coeff B & t & Sig & Kesimpulan \\
\hline Constant & 131,326 & 23,214 & 0,000 & 0,000 \\
Ukuran perusahaan & $-3,390$ & $-5,718$ & Signifikan \\
Rasio debt to equity & 0,182 & 2,644 & 0,008 & Signifikan \\
Profitabilitas & $-3,870$ & $-5,130$ & 0,000 & Signifikan \\
Subsidiari dari perusahaan multinasional & $-20,920$ & $-14,090$ & 0,000 & Signifikan \\
Ukuran kantor audit & $-6,633$ & $-11,400$ & 0,000 & Signifikan \\
Audit fees & $-3,177$ & $-2,967$ & 0,003 & Signifikan \\
Klasifikasi industri & 21,098 & 12,653 & 0,000 & Signifikan \\
Umur perusahaan & $-0,109$ & $-7,329$ & 0,000 & Signifikan \\
Tahun tutup buku perusahaan & 1,057 & 1,891 & 0,059 & Tidak Signifikan \\
Opini audit & $-9,322$ & $-3,675$ & 0,000 & Signifikan \\
\hline
\end{tabular}

\section{Uji Asumsi Klasik}

Hasil uji normalitas menyatakan bahwa penyebaran data mengikuti arah garis diagonal sehingga dapat dikatakan bahwa asumsi ini terpenuhi. Demikian pula uji multikolinieritas menunjukkan bahwa nilai tolerance dari sepuluh variabel independen lebih besar dari 0,1 . Sedangkan nilai VIF untuk kesepuluh variabel independen lebih kecil dari 10, artinya antar variabel independen tidak berkorelasi atau asumsi multikolinieritas terpenuhi.
Hasil olahan data menyatakan bahwa angka Durbin-Watson adalah sebesar 0,822 yang berada diantara angka 2 dan -2. Hal ini berarti tidak terjadi autokorelasi. Uji heteroskedastitas menunjukkan bahwa titik-titik pengamatan tidak membentuk suatu pola tertentu yang teratur. Titik-titik tersebut tersebar di atas dan di bawah angka nol pada sumbu $\mathrm{Y}$ yang berarti tidak terjadi heteroskedastisitas. Dari hasil uji asumsi klasik ini menyatakan bahwa model regresi yang diajukan dapat digunakan. 


\section{Uji Hipotesis}

Hasil uji $\mathrm{F}$ menunjukkan bahwa nilai $\mathrm{F}$ sebesar 127,706 dengan signifikansi sebesar 0,000 lebih kecil dari 0,05. Hasil tersebut membuktikan bahwa model regresi dapat digunakan untuk memprediksi variabel dependen. Dengan kata lain, keterlambatan audit secara bersama-sama dipengaruhi oleh semua variabel yang digunakan dalam penelitian ini. Sedangkan hasil uji t dapat dilihat pada Tabel 4.

Persamaan regresi yang dapat dibentuk berdasarkan hasil uji pada tabel di atas adalah sebagai berikut:

\section{AUDLAY $=131,326-3,390$ LASSTS $+0,182$ DRAT - 3,870 PRFT - 20,920 MCM $-6,633 \mathrm{INLNK}-3,177$ AUDFEE + 21,098 INDT - 0,109 AGE + 1,057 FINYR - 9,322 OPINI + e}

Persamaan regresi yang terbentuk di atas menjelaskan koefisien masing-masing variabel independen terhadap variabel dependen. Dari sepuluh variabel yang dimasukkan ke dalam model regresi, sembilan variabel yang berpengaruh signifikan terhadap variabel dependen, yaitu ukuran perusahaan. Sedangkan satu variabel terbukti tidak memiliki hubungan signifikan dengan ukuran perusahaan. Sembilan variabel yang memiliki hubungan signifikan tersebut adalah rasio debt to equity, profitabilitas, subsidiari dari perusahaan multinasional, ukuran kantor audit, audit fees, klasifikasi industri, umur perusahaan, dan opin audit. Sedangkan variabel yang tidak berpengaruh signifikan terhadap keterlambatan audit adalah variabel tahun tutup buku perusahaan.

Ukuran perusahaan memiliki nilai signifikansi sebesar 0,000, nilai tersebut kurang dari 0,05 menunjukkan bahwa ukuran perusahaan mempunyai pengaruh signifikan terhadap keterlambatan audit. Sedangkan nilai koefisien regresi sebesar -3,390 menunjukkan bahwa ukuran perusahaan mempunyai arah pengaruh negatif terhadap keterlambatan audit. Artinya semakin besar ukuran perusahaan maka akan semakin pendek keterlambatan auditnya. Hal tersebut dikarenakan perusahaan yang besar umumnya memiliki internal kontrol yang dapat mengurangi kesalahan dalam penyajian laporan keuangan, sehingga waktu audit yang diperlukan akan lebih pendek.

Hasil penelitian ini menunjukkan bahwa variabel rasio debt to equity memiliki pengaruh yang signifikan terhadap keterlambatan audit, dengan nilai koefisien regresi sebesar 0,182. Artinya semakin besar nilai rasio debt to equity maka semakin panjang keterlambatan audit yang terjadi. Perusahaan akan melakukan penundaan pelaporan keuangan akibat dari tingginya resiko perusahaan karena tingginya rasio debt to equty. Nilai koefisien regresi sebesar -3,870 pada variabel profitabilitas yang ternyata memiliki pengaruh signifikan terhadap keterlambatan audit berarti bahwa perusahaan yang melaporkan laba akan memiiliki keterlambatan audit yang lebih pendek daripada perusahaan yang melaporkan rugi. Hal ini dikarenakan informasi laba dapat memberikan dampak pada harga saham dan indikator lainnya. Ada kecenderungan perusahaan lebih cepat melaporkan laba (good news) daripada rugi (bad news).

Variabel subsidiari dari perusahaan multinasional juga mempunyai pengaruh signifikan terhadap keterlambatan audit pada nilai signifikansi 0.01. Nilai koefisien regresi sebesar -20,920 menunjukkan bahwa subsidiari dari perusahaan multinasional mempunyai arah pengaruh negatif terhadap keterlambatan audit. Hasil tersebut menyatakan bahwa, perusahaan yang merupakan subsidiari dari perusahaan multinasional akan memiliki keterlambatan audit yang pendek. Hal tersebut dikarenakan subsidiari dari perusahaan multinasional akan menyelesaikan laporan keuangan mereka lebih cepat setelah berakhirnya periode akuntansi untuk digunakan sebagai tujuan konsolidasi.

Penelitian ini membuktikan bahwa ukuran kantor audit mempunyai pengaruh signifikan terhadap keterlambatan audit. Koefisien variabel yang bertanda negatif menunjukkan semakin besar ukuran kantor audit maka keterlambatan audit semakin pendek. Hal tersebut dikarenakan perusahaan audit yang besar memiliki personil dengan kompetensi yang baik, fasilitas dang pengalaman dalam bidang audit.

Dilihat dari nilai signifikansinya variabel audit fees mempunyai pengaruh signifikan terhadap keterlambatan audit. Sedangkan nilai koefisien regresinya menunjukkan bahwa audit fees mempunyai arah pengaruh negatif terhadap keterlambatan audit, yang artinya semakin besar audit fees maka semakin pendek keterlambatan audit. Hasil penelitian ini membuktikan bahwa walaupun audit fees yang besar umumnya terjadi pada perusahaan berukuran besar karena kompleksitas perusahaan yang makin tinggi, namun hal tersebut tidak menyebabkan panjangnya waktu audit yang diperlukan.

Variabel klasifikasi industri dalam penelitian ini mempunyai nilai signifikansi kurang dari 0,01. Ini membuktikan bahwa terdapat pengaruh signifikan antara klasifikasi industri terhadap keterlambatan audit. Sedangkan nilai koefisien 
regresi yang bertanda positif menunjukkan bahwa jika perusahaan termasuk perusahaan non keuangan, maka akan memiliki keterlambatan audit yang panjang karena audit memerlukan waktu lebih panjang pada perusahaan non keuangan, terutama pada rekening inventory.

Hasil uji t juga menyatakan bahwa semakin lama suatu perusahaan berdiri maka semakin pendek keterlambatan auditnya, karena perusahaan mempunyai prosedur internal kontrol yang dapat mengurangi terjadinya kesalahan dalam penyajian laporan keuangan. Oleh karena itu, tidak akan menyebabkan terjadi penundaan pelaporan keuangan. Sedangkan variabel tahun tutup buku perusahaan tidak memiliki pengaruh signifikan terhadap keterlambatan audit karena nilai signifikansinya lebih besar dari 0,05. Hal ini mungkin dikarenakan walaupun tahun tutup buku perusahaan terjadi selama bulan sibuk, namun perusahaan tetap harus melaporkan laporan keuangan sesuai dengan peraturan yang ditetapkan oleh Bursa Efek Malaysia yaitu selambat-lambatnya pada akhir bulan keenam setelah periode akuntansi. Hasil uji t pada variabel opini audit menyatakan bahwa opini audit mempunyai pengaruh signifikan terhadap keterlambatan audit. Jika perusahaan menerima standar opini atau unqualified opinion maka keterlambatan audit akan pendek, karena standar opini atau unqualified opinion diartikan sebagai berita baik bagi perusahaan sehingga perusahaan tidak akan melakukan penundaan pelaporan keuangan.

Hasil uji adjusted $\mathrm{R}^{2}$ dalam penelitian ini adalah sebesar 0,271 atau 27,1\% yang menunjukkan bahwa variabel independen dapat menjelaskan variabel dependen sebesar 27,1\%, sedangkan $72,9 \%$ keterlambatan audit dijelaskan oleh faktor lain yang tidak terdapat dalam model penelitian. Faktor-faktor lain yang mungkin berpengaruh juga terhadap keterlambatan audit tetapi belum atau tidak dimasukan dalam model penelitian adalah variabel yang berhubungan dengan corporate governance seperti ownership concerntation, board/audit comittee independence, duality of CEO, board size, audit committee financial expertis, jumlah komite audit, jumlah rapat komite audit, dan sebagainya (Afify, 2009; Nor, Shafie dan Hussin, 2010).

\section{KESIMPULAN DAN SARAN}

Hasil penelitian pada Bursa Efek Malaysia menunjukkan bahwa ukuran perusahaan, rasio debt to equity, profitabilitas, subsidiari dari perusahaan multinasional, ukuran kantor audit, audit fees, klasifikasi industri, umur perusahaan, dan opin audit mempunyai pengaruh signifikan terhadap keterlambatan audit. Sedangkan tahun tutup buku perusahaan tidak mempunyai pengaruh signifikan terhadap keterlambatan audit. Adapun saran yang dapat diberikan adalah perlunya penambahan variabel baru dalam model penelitian seperti ownership concentratation, board/audit comittee independence, duality of CEO, board size, audit committee financial expertise, jumlah komite audit, jumlah rapat komite audit, serta mencari literatur tambahan terkait variabel subsidiari dari perusahaan multinasional.

\section{DAFTAR PUSTAKA}

Afify, H. A. E. (2009). Determinants of Audit Report Lag: Does Implementing Corporate Governance Have Any Impact? Empirical Evidence from Eqypt. Journal of Applied Accounting Research, 10(1), 56-86.

Ahmad, A. C. \& Abidin, S. (2008). Audit Delay of Listed Companies: A case of Malaysia, International Business Research, 1(4).

Aktas, R. \& Kargin, M. (2011). Timeliness of Reporting and the Quality of Financial Information. International Research Journal of Finance and Economics, 63, 1450-2887.

Al-Ajmi, J. (2008). Audit and Reporting Delays: Evidence from an Emerging Market, Advances in Accounting, Incorporating Advances in International Accounting, 24, 217-226.

Al-Ghanem, W. \& Hegazy, M. (2011). An Empirical Analysis of Audit Delay and Timeliness of Corporate Financial Reporting in Kuwait. Eurasian Business Review, 1, 7390.

Ashton, R. H., Willingham, J. J., \& Elliott, R. K. (1987). An Empirical Analysis of Audit Delay. Journal of Accounting Research, 25(2).

Ashton, R. H., Graul, P. R., \& Newton, J. D. 1989. Audit Delay and the Timeliness of Corporate Reporting. Contemporary Accounting Research, 5(2), 657-673.

Aubert. F. (2009). Determinants of Corporate Financial Reporting Lag: The French Empirical Evidence. Journal of Accounting and Taxation, 1(3), 035-060.

Belkaoui, A. R. (2004). Accounting Theory. Pat Bond Publisher. Cengange Learning EMEA. Singapore.

Carslaw, C. A. P. N. \& Kaplan, S. E. (1991). An Examination of Audit Delay: Further Evidence from New Zealand. Accounting and Business Research, 22(85), 21-32.

Dogan, M., Coskun, E., \& Celik, O. (2007). Is Timing of Financial Reporting Related to Firm 
Performance? An Examination on ISE Listed Companies. International Research Journal of finance and Economics, 12, 1450-2887.

Faghemi, T. O. \& Uadiale, O. M. (2011). An Appraisal of the Determinants of Timeliness of Audit Report in Nigeria: Evidence from Selected Quoted Companies. New Orleans International Academic Conference.

Gitman, L. J. \& Joehnk, G. H. (2008). Fundamentals of investing USA: Pearson-Addison Wesley.

Ghozali, I. (2001). Aplikasi analisis multivariate dengan program SPSS. Semarang: Badan Penerbitan Universitas Diponegoro.

Hashim, U. J. B. \& Rahman, R. B. A. (2011). Audit Report lag and the effectiveness of audit committee. International Bulletin of Business Administration. ISSN: 1451-243X. Issue 10.

Hope, O. K. \& Langli, J. C. (2008). Auditor independence in a private firm setting. Norwegian School of Economic and Business Administration.

Ikatan Akuntan Indonesia. (1998). Pernyataan standar akuntansi keuangan. No. 1.

Ika, S. R. \& Ghazali, N. A. M. (2012). Audit committee effectiveness and timeliness of reporting: Indonesia evidence. Managerial Auditing Journal, 27(4), 403-424.

Iskandar, M. J. \& Trisnawati, E. (2010). Faktorfaktor yang mempengaruhi audit report lag pada perusahaan yang terdaftar di Bursa Efek Indonesia. Jurnal Bisnis dan Akuntansi, 12(3), 175-186.

Iyoha, F. O. (2012). Company attributes and the timeliness of financial reporting in Nigeria. Business Intelligence Journal, 5(1).

Ishak, I., Sidek, A. S. M., \& Rashid, A. A. (2010). The effect of company ownership on the timeliness of financial reporting: Empirical evidence from Malaysia. Unitar E-Journal, $6(2)$.

Jaggi, B. \& Tsui, J. (1999). Determinants of audit report lag: Further evidence from Hong Kong. Accounting and Business Research, 30(1), 17 28.

Joshi, A. (2005). Timeliness in corporate reporting of Indian Public Financial Institutions (IPFIs). Udyog Pragati, 29(2).

Kadir, A. (2011). Faktor-faktor yang berpengaruh terhadap ketepatan waktu pelaporan keuangan: Studi empiris pada perusahaan manufaktur di Bursa Efek Jakarta. Jurnal Manajemen dan Akuntansi, 12(1).

Karim. W. \& Ahmed. J. U. (2005). Does regulatory change improve financial reporting timeliness? Evidence from Bangladeshi listed companies. Working Paper Series, 30.

Kartika, A. (2009). Faktor-faktor yang mempengaruhi audit delay di Indonesia: Studi empiris pada perusahaan-perusahaan LQ 45 yang terdaftar di Bursa Efek Jakarta. Jurnal Bisnis dan Ekonomi (JBE), 16(1), 1-17.

Lianto, N. \& Kusuma, B. H. (2010). Faktor-faktor yang mempengaruhi terhadap audit report lag. Jurnal Bisnis dan Akuntansi, 12(2), 97106.

Lee, H. Y. \& Jahng, G. J. (2008). Determinants of Audit Report Lag: Evidence from Korea- An Examination of Auditor-Related Factors. The Journal of Applied Busines Research, 24(2).

McGee, R. W. \& Yuan, X. (2012). Corporate Governance and the Timeliness of Financial Reporting: A Comparative Study of the People's Republic China, the USA and the European Union. Journal of Asia Business Studies, 6(1).

Meiden, W. C. (2007). Variabel Total Lag Laporan Keuangan Perusahaan Manufaktur di BEJ”, Akuntabilitas, 7(1).

Modugu, P. K., Eragbhe, E., \& Ikhatua, O. J. (2012). Determinants of Audit Delay in Nigeria Companies: Empirical Evidence. Research Journal of Finance and Accounting, 3(6).

Ng, P. P. H. \& Tai, B. Y. K. (1994). An Empirical Examination of the Determinants of Audit Delay in Hong Kong. British Accounting Review, 26, 43-59.

Nor, M. N. M., Shafie, R., \& Hussin, W. N. W. (2010). Corporate and Audit Report Lag in Malaysia. Asian Academy of Management Journal of Accounting and Finance, 6(2), 5784.

Oladipupo, A. O. (2011). Impact of Corporate International Linkage on the Incidence of Audit Delay in Nigeria. Journal of Research in National Development, 9(1), 1596-8303.

Owusu-Ansah, S. (2000). Timeliness of Corporate Financial Reporting in Emerging Capital Market: Empirical Evidence from the Zimbabwe Stock Exchange. Forthcoming in Accounting \& Business Reseach, 30(3).

Rachmawati, S. (2008). Pengaruh Faktor Internal dan Eksternal Perusahaan terhadap Audit Delay dan Timeliness. Jurnal Akuntansi dan Keuangan, 10(1).

Santoso, S. (2000). Buku latihan SPSS statistik parametric. Jakarta: PT. Elex Media Komputindo.

Shukeri, S. N. \& Nelson, S. P. (2011). Timeliness of Annual Report: Some Empirical Evidence from Malaysia. Research Paper.

Sudrajat. (2009). Fakor-faktor yang Mempengaruhi Waktu Penyelesaian Pelaporan Keuangan: Studi Kasus pada Perusahaan Manufaktur yang Tercatat di Bursa Efek Indonesia. Jurnal Ekonomi, Keuangan, Perbankan, dan Akuntansi, 1(2). 
Shulthoni, M. (2012). Determinan Audit Delay dan Pengaruh terhadap Reaksi Investor: Studi Empiris pada Perusahaan yang Listing di BEI tahun 2007-2008. Jurnal Akuntansi dan Ekonomis Bisnis, 1(1).

Turel, A. (2010). Timeliness of Financial Reporting in Emerging Capital Markets: Evidence from Turkey. Journal of the School of Business Administration, 39(2), 227-240.
Utami, W. (2006). Analisis Determinan Audit Delay Kajian Empiris di Bursa Efek Jakarta. Bulletin Penelitian, (9).

Wang, J. \& Song, L. (2006). Timeliness of Annual Reports of Chinese Listed Companies. Journal of Chinese Economic and Business Studies, 4(3), 241-257.

Yaacob, N. M. \& Ahmad, A. C. (2011). IFRS adoption and audit timeliness: Evidence from Malaysia. The Journal of American Academy of Business, Cambridge, 17(1). 